\section{Az észak-alföldi mezőgazdasági vállalkozások pénzügyi helyzetének elemzése 1997-1999-es adatok alapján}

\author{
Rózsa Attila \\ Debreceni Egyetem Agrártudományi Centrum, \\ Agrárgazdasági és Vidékfejlesztési Intézet, \\ Számviteli és Pénzügyi Tanszék, Debrecen
}

\section{ÖSSZEFOGLALÁS}

A mezögazdasági tevékenységet folytató vállalkozások jövedelme a mezögazdaság sajátosságaiból adódóan széles határok között változik. Az elemzés a Hajdú-Bihar és SzabolcsSzatmár-Bereg megyei mezögazdasági vállalkozások pénzügyi helyzetének vizsgálatával foglalkozik, az Igazságügyi Minisztérium Céginformációs és Cégnyilvántartási Osztály által rendelkezésre bocsátott 1997-99 éves beszámolók alapján. Az elemzés során az adatok megyénként csoportositva, átlagolva kerültek analizisre.

A vizsgált vállalkozások nyereségesen gazdálkodtak, viszont a cash flow-kimutatást tanulmányozva látható, hogy nem minden esetben voltak képesek pénzkiadásaikat pénzbevételeikböl fedezni. Mind a két megye esetében nagy hangsúlyt fektettek fejlesztésre, beruházások támogatására. Valószinü, hogy ez a későbbiekben, bevételben is megvalósuló hasznot fog eredményezni.

Összességében két megye mezögazdasági vállalkozásai közül ezen elemzés alapján nem adható egyértelmü válasz arra vonatkozóan, hogy melyik megye mezögazdasági vállalkozásai vannak jobb helyzetben, illetve a kialakult eltérések mire vezethetők vissza. A rendelkezésre álló adatok alapján ezen kérdésekre nem lehet egyértelmü választ adni, de a későbbiekben ennek megitélése érdekében további vizsgálatokat és kiegészitö adatgyüjtést fogok végezni.

\section{SUMMARY}

The income of agricultural enterprises varies greatly according to the type of agricultural production.

We analysed the financial situation of some agricultural companies from Szabolcs-Szatmár-Bereg and Hajdú-Bihar counties. We got the data from the Department of Justice from reports made between 1997-1999. The available data was classified and averaged by counties.

Although the management of the examined enterprises ensured profit, closer analyses of their cash flows reveal that, at least in some cases, expenses were not always coverable, despite income. Both counties, major emphasis was on improvement and support investments. It is highly probable that these investments will later result in an increasing income level and profit.

Altogether we cannot say which county enjoys a better situation, and what the reasons for the differences are. Further data collection and analyses are needed to find the answers.

\section{BEVEZETÉS}

A piacgazdaság kialakulását és fejlődését követően a tulajdonosoknak, a hitelezőknek és a gazdaság más szereplőinek egyaránt megnőtt az igénye a vállalkozás vagyoni, pénzügyi és jövedelmi helyzetét, a valóságnak megfelelően bemutató információk iránt. A számviteli törvény értelmében, a törvény hatálya alá tartozó gazdálkodó szervezeteknek a törvényben meghatározott követelményeknek megfelelően beszámolási és könyvvezetési kötelezettségük van.

A vagyoni helyzetről a mérleg, a jövedelmi helyzetről pedig az eredménykimutatás tájékoztat. Ezzel szemben pénzügyi helyzetről a mérlegből és az eredménykimutatásból is nyerhetünk ismereteket, de ez önmagában kevés a körültekintő elemzéshez. Ehhez nyújt hasznos ismereteket, az éves beszámolót készítő vállalkozásoknál a cash flow-kimutatás.

A likviditás a gazdasági élet valamely szereplöjének olyan helyzete, amikor fizetési kötelezettségét határidőre ki tudja egyenlíteni. A likviditás statikus jellemző, amely egy vállalkozás adott időpillanatban fennálló fizetőképességét, illetve fizetésképtelenségét jelenti (Tóth, 1993). A fizetőképesség megítélésének a kényszere felgyorsította a pénzügyi helyzet elemzésével kapcsolatos munkát. Ez érthető, hiszen a pénz a vállalkozás éltető ereje volt és az is marad mindig (Collins, 1998). Mennyisége és mozgása fontos gazdasági jellemző, amelynek értékelése külön beszámoló készítését igényli.

1997. január elsejétől az éves beszámolót készítő vállalkozásoknak a kiegészítő melléklethez csatolni kell legalább a számviteli törvényben meghatározott részletességgel elkészített cash flow-kimutatást. Így napjainkra a magyar számvitelnek is részévé vált az a dokumentum, amely Nyugat-Európában és az Egyesült Államokban már régóta a vállalati beszámolók részét képezi.

A cash flow a világ országaiban azonos jelentéssel bír. A cash egy angol kifejezés, amely a mindennapi szóhasználatban készpénzt, a flow pedig áramlást jelent. Azaz a cash flow pénzáramlás, pénzeszközváltozás.

A cash flow a vállalkozás egy meghatározott időtartamon belül realizált pénzbevételeinek és pénzkiadásainak különbsége (a vállalkozás pénzeszközeiben bekövetkezett változás, ami a mérlegből közvetlenül is megállapítható) (Kozma, 1999).

A pénzeszközök központi szerepét támasztja alá, hogy szinte minden gazdasági eseménynek van azonnali vagy későbbi időpontban felmerülő pénzeszközszükséglete.

\section{A CASH FLOW-KIMUTATÁS CÉLJA, SZEREPE AZ INFORMÁCIÓ-SZOLGÁLTATÁSBAN}

A cash flow-kimutatás többek között választ ad a következő kérdésekre: 
- Honnan származnak a vállalkozás pénzbevételei a beszámolási időszak alatt?

- Mire használták fel a pénzeszközöket ugyanezen időszak alatt?

- Képes volt-e a társaság alapvető működése során a szükséges pénzeszközök előteremtésére, vagy esetleg bizonyos tárgyi eszközeinek, más befektetéseinek eladására kényszerült annak érdekében, hogy pénzeszközeit elfogadható szinten tartsa?

- A beszámolási időszak alatt a társaság rászorult-e hitelek felvételére?

- A rendelkezésre álló pénzeszközeit a társaság az adósságainak törlesztésére kényszerült-e felhasználni, vagy azokat a tevékenysége bővítését elősegítő beruházásokra tudta elkölteni?

- Hogyan valósult meg a társaság növekedésének és terjeszkedésének finanszírozása? (Nagy, 1998)

A cash flow-kimutatásból megállapítható, hogy a fejlesztések fedezetében milyen mértékben vesznek részt saját és idegen források, továbbá a pénzfelhasználáson belül milyen részarányt képez a nyereségadó, a hitelek törlesztése, a beruházások pénzügyi teljesítése, az anyagi ösztönzési kifizetések és a pénzügyi befektetések (Forgács, 1991).

A cash flow-kimutatás célja:

- képet nyújt a társaság fizetőképességéröl, jövedelemtermelő képességéről,

- tájékoztat a vállalkozás beszámolás időszak alatti pénzeszköz bevételeiről és kiadásairól (Koblencz, 1995),

- pénzeszköz alapon nyújt tájékoztatás a vállalkozás müködési, befektetési és finanszírozási tevékenységéről (Nagy, 1998),

- tájékoztatja a vezetőket korábbi döntéseik helyességéről, valamint a hitelezőket a vállalkozás kötelezettség-teljesítési és osztalékfizetési képességéről (Bíró et al., 1997).

\section{AZ EREDMÉNY- ÉS A CASH FLOW- KIMUTATÁS ELEMZÉSE}

A dolgozat Hajdú-Bihar és Szabolcs-SzatmárBereg megyei mezőgazdasági vállalkozások pénzügyi helyzetének elemzésével foglalkozik, az Igazságügyi Minisztérium Céginformációs és Cégnyilvántartási Osztály által rendelkezésre bocsátott 1997-es 1998-as és 1999-es éves beszámolók alapján. Az elemzés során az adatok megyénként átlagolva kerültek feldolgozásra.

Tapasztalataim alapján a közzétételi kötelezettség alá tartozó cégek jelentős része - a törvényi szabályozás ellenére, szankciók hiányában - nem, vagy csak hiányosan tesznek eleget az elöírásoknak. 1997 és 1999 között Hajdú-Bihar megyében, a nagy számú működő mezőgazdasági társaság ellenére mindössze 18, Szabolcs-Szatmár-Bereg megyében 8 mezőgazdasági vállalkozás jövedelemének elemzését lehetett elvégezni.

A vizsgálat során az adatok megyénként, átlagolva kerültek analízisre. Ezzel arra keresve a választ, hogy vannak-e különbségek a megyék között, és ha igen, akkor melyik helyzete kedvezőbb.

$\mathrm{Az}$ elemzés 1997-tel kezdődik, mivel Magyarországon ez az év volt az első, amikor az éves beszámolót készítő vállalkozásoknak cash flowkimutatást is kellett készíteni. A cash flowkimutatásnál az egyes sorok átlagos értékei a pénzeszköz-változás százalékában kerültek kifejezésre.

A feldolgozott adatok alapján 1997 és 1999 között a vállalkozások nyereségesen gazdálkodtak, de pénzeszközváltozás területén eltérések tapasztalhatók. A pénzeszközáramlást a Hajdú-Bihar megyei vállalkozásoknál az 1. táblázat szemlélteti.

Hajdú-Bihar megyében 1997-ben a müködési és befektetési pénzáramlás negatívan alakult, amelyet a finanszírozási tevékenységből származó pénzbevétel ellensúlyozott. Ez összességében pozitív pénzeszköz változás kialakulásához vezetett. A negatív müködési cash flow kialakulásában nagy szerepe volt a készletek nagy mértékü növekedésének, amelyet az adózás előtti eredmény és az értékcsökkenés sem tudott ellensúlyozni. A készletbeszerzés értéke meghaladja az értékesített készletek értékét, azaz a többlet beszerzés a pénzeszközök csökkenését vonta maga után. A vevők állományának növekedése és az egyéb rövid lejáratú kötelezettségek csökkenése semlegesítette a szállítókkal szembeni kötelezettség növekedését. A befektetett eszközök beszerzésére fordított összeg nagy részét a befektetett eszközök eladásából származó bevétel biztosította. A felvett jelentős összegü hitel fedezte a törlesztést, a szokásos tevékenység és fejlesztés pénzeszköz igényét.

1998-ban kedvezőbb helyzet alakult ki, a szokásos tevékenységből származó pénzeszközök hozzájárultak a pénzkiadások finanszírozásához. Az adózás előtti eredmény és az elszámolt amortizáció bevételt biztosító hatását a készletek, és a vevők állományának a növekedése csökkentette. A befektetett eszközök beszerzésének pénzszükséglete befektetett eszközök értékesítésén túl a müködésből és a finanszírozási tevékenységből került kiegészítésre. Kedvező változás, hogy a felvett hitel értéke nem sokkal haladja meg a hiteltörlesztés összegét. Megfigyelhető, hogy a vevőkkel szembeni követelést nem tudták pénzbevétel formájában realizálni és a készleteik mennyiségének a növekedése is készpénz csökkenést eredményezett. Figyelmet fordítanak új eszközök beszerzésére, és sikerült a hitelfelvételt a törlesztési kötelezettség szintje közelébe csökkenteni.

1999-ben összességében negatív pénzeszköz változás következet be, azaz a tárgyévi pénzbevételeket meghaladta a pénzkiadások mértéke. Összességében nem biztos, hogy ez a változás kedvezőtlennek tekinthető. $\mathrm{Az}$ adózás előtti eredmény és az elszámolt amortizáció bevételt biztosító hatását az egyéb rövid lejáratú kötelezettségek csökkenése és a vevők állományának a növekedése csökkentette. A szállítók állománya növekedett valószínűleg azért, mert a szállítókkal szembeni kötelezettségét ki tudták tolni. A vevőkkel szembeni követelésük az előző évhez képest szintén 
növekedett. A befektetett eszközök beszerzését, ami szintén jelentős mértékü egyrészt a befektetett eszközök értékesítése, másrészt szokásos tevékenység pénzbevétele biztosította. Kedvezö változás, hogy a felvett hitel kevesebb, mint a hiteltörlesztés, azaz a vállalkozás által megtermelt pénzmennyiség is felhasználható a korábban felvett hitelek törlesztésére. Itt a vállalkozásoknak már lehetősége volt arra, hogy a müködésük során elöteremtett pénzbevételeik fedezetet nyújtsanak, nemcsak a müködésre, fejlesztésre, hanem a korábban felvett hitelek törlesztésére is.

Néhány Hajdú-Bihar megyei mezőgazdasági vállalkozás 1997-1999 közötti cash flow-kimutatás adatainak átlaga

\begin{tabular}{|c|c|c|c|c|c|c|c|c|c|}
\hline \multirow[b]{2}{*}{ Cash flow-kimutatás(1) } & \multicolumn{3}{|c|}{1997} & \multicolumn{3}{|c|}{1998} & \multicolumn{3}{|c|}{1999} \\
\hline & átlag(2) & $\begin{array}{c}\text { pénze. } \\
\text { változás } \\
\%(3) \\
\end{array}$ & $\begin{array}{c}\text { múk. } \\
\text { cash flow } \\
\%(4) \\
\end{array}$ & átlag(2) & \begin{tabular}{|c|} 
pénze. \\
változás \\
$\%(3)$
\end{tabular} & \begin{tabular}{|c|} 
mük. \\
cash flow \\
$\%(4)$ \\
\end{tabular} & átlag(2) & \begin{tabular}{|c|} 
pénze. \\
változás \\
$\%(3)$ \\
\end{tabular} & \begin{tabular}{|c} 
mük. \\
cash flow \\
$\%(4)$ \\
\end{tabular} \\
\hline Müködési cash flow(4) & -10595 & $-320,1$ & $-100,0$ & 19336 & 426,6 & 100,0 & 55187 & 6287,3 & 100,0 \\
\hline Adózás előtti eredmény +/-(5) & 45518 & 1375,2 & 429,6 & 64421 & 1421,4 & 333,2 & 24800 & 2825,4 & 44,9 \\
\hline Elszámolt amortizáció +(6) & 19228 & 580,9 & 181,5 & 27896 & 615,5 & 144,3 & 23383 & 2664,0 & 42,4 \\
\hline Elszámolt értékvesztés +(7) & 1833 & 55,4 & 17,3 & 2227 & 49,1 & 11,5 & 8659 & 986,5 & 15,7 \\
\hline Céltartalék képzés és felhasználás különbözete +/-(8) & 3337 & 100,8 & 31,5 & 2144 & 47,3 & 11,1 & 11560 & 1317,0 & 20,9 \\
\hline Befektetett eszközök értékesítésének eredménye $+/-(9)$ & -166 & $-5,0$ & $-1,6$ & -3218 & $-71,0$ & $-16,6$ & -1312 & $-149,5$ & $-2,4$ \\
\hline Szállítói kötelezettségek változása +/-(10) & 18967 & 573,0 & 179,0 & 9400 & 207,4 & 48,6 & 12164 & 1385,8 & 22,0 \\
\hline Egyéb rövid lejáratú kötelezettségek változása +/-(11) & -13931 & $-420,9$ & $-131,5$ & 15119 & 333,6 & 78,2 & -11188 & $-1274,6$ & $-20,3$ \\
\hline Passziv időbeli elhatárolások változása +/-(12) & 2889 & 87,3 & 27,3 & 5372 & 118,5 & 27,8 & 6168 & 702,7 & 11,2 \\
\hline Vevőkövetelés változása +/-(13) & -4436 & $-134,0$ & $-41,9$ & -31716 & $-699,8$ & $-164,0$ & -4513 & $-514,2$ & $-8,2$ \\
\hline Forgóeszközök változása(14) & -69206 & $-2090,8$ & $-653,2$ & -51295 & $-1131,8$ & $-265,3$ & 2534 & 288,7 & 4,6 \\
\hline Aktív időbeli elhatárolások változása +/-(15) & -403 & $-12,2$ & $-3,8$ & -1194 & $-26,4$ & $-6,2$ & -474 & $-54,0$ & $-0,9$ \\
\hline Fizetett adó (nyereség után) -(16) & -9064 & $-273,8$ & $-85,6$ & -9609 & $-212,0$ & $-49,7$ & -10635 & $-1211,6$ & $-19,3$ \\
\hline Fizetett osztalék, részesedés -(17) & -5162 & $-155,9$ & $-48,7$ & -10211 & $-225,3$ & $-52,8$ & -5960 & $-679,0$ & $-10,8$ \\
\hline Befektetési cash flow(18) & -39431 & $-1191,3$ & $-372,2$ & -62751 & $-1384,6$ & $-324,5$ & -22644 & $-2579,8$ & $-41,0$ \\
\hline Befektetett eszközök beszerzése -(19) & -74640 & $-2255,0$ & $-704,5$ & -87153 & $-1923,0$ & $-450,7$ & -46119 & $-5254,3$ & $-83,6$ \\
\hline Befektetett eszközök eladása $+(20)$ & 34718 & 1048,9 & 327,7 & 23881 & 526,9 & 123,5 & 23451 & 2671,7 & 42,5 \\
\hline Kapott osztalék $+(21)$ & 491 & 14,8 & 4,6 & 547 & 12,1 & 2,8 & 24 & $-2,7$ & 0,0 \\
\hline Finanszírozási cash flow(22) & 53336 & 1611,4 & 503,4 & 47948 & 1058,0 & 248,0 & -33420 & $-3807,5$ & $-60,6$ \\
\hline Részvénykibocsátás bevétele (tökebevonás) +(23) & 0 & 0,0 & 0,0 & 4255 & 93,9 & 22,0 & 85 & 9,7 & 0,2 \\
\hline Kötvénykibocsátás bevétele $+(24)$ & 0 & 0,0 & 0,0 & 0 & 0,0 & 0,0 & 0 & 0,0 & 0,0 \\
\hline Hitelfelvétel +(25) & 278417 & 8411,5 & 2627,9 & 328607 & 7250,7 & 1699,5 & 769546 & 87673,5 & 1394,4 \\
\hline Véglegesen kapott pénzeszközök +(26) & 6943 & 209,8 & 65,5 & 10782 & 237,9 & 55,8 & 2860 & 325,8 & 5,2 \\
\hline Részvénybevonás (tökeleszállitás) -(27) & -5478 & $-165,5$ & $-51,7$ & -10847 & $-239,3$ & $-56,1$ & -630 & $-71,8$ & $-1,1$ \\
\hline Kötvényvisszafizetés -(28) & 0 & 0,0 & 0,0 & -8945 & $-197,4$ & $-46,3$ & 0 & 0,0 & 0,0 \\
\hline Hiteltörlesztés-visszafizetés -(29) & -226337 & $-6838,1$ & $-2136,3$ & -275756 & $-6084,5$ & $-1426,2$ & -789289 & $-89922,8$ & $-1430,2$ \\
\hline Véglegesen átadott pénzeszközök -(30) & -209 & $-6,3$ & $-2,0$ & -152 & $-3,3$ & $-0,8$ & -15991 & $-1821,9$ & $-29,0$ \\
\hline Pénzeszköz változás(3) & 3310 & 100 & 31,2 & 4532 & 100,0 & 23,4 & -878 & $-100,0$ & $-1,6$ \\
\hline
\end{tabular}

Table 1: Some Hajdú-Bihar country agricultural companies 1997-1999 average cash flow statment

Cash flow statment(1), Average(2), Cash flow(3), Operative cash flow(4), Pre-tax profit(5), Accounted depreciation(6), Accounted loss in value(7), Provisions change(8), Achievement of invested assets sale(9), Trade creditors change(10), Other short term liabilities change(11), Accrued liabilities change(12), Trade debtors change(13), The change of current assets (without trade debtors and cash)(14), Accruals change(15), Paid tax(16), Paid dividend(17), Investment cash flow(18), Invested assets bay(19), Invested assets sale(20), Received dividend(21), Financial cash flow(22), Share issue capture(23), Flotation capture(24), Credit admission(25), Cash received permanently(26), Withdra wal of stocks(27), Bond refund(28), loan repayments(29), Cash handed over permanently(30)

A Szabolcs-Szatmár-Bereg megyei vállalkozások szintén nyereségesen gazdálkodtak, de pénzáramlásuk nem alakult ilyen kedvezően (2. táblázat).

1997-ben a pozitív pénzáramlás kialakulása elsősorban a finanszírozási tevékenységre vezethető vissza, mivel a müködési és a befektetési tevékenység egyaránt negatívan alakult. A negatív szokásos tevékenység kialakulásában jelentős szerepe volt a jelentős mértékü egyéb rövid lejáratú kötelezettségeknek. Ezt az amortizáció, az értékvesztés, a vevők és a készletek állománya sem tudta megfordítani. A befektetések nagyobb része sajnos csak hitelből valósult meg. A hitelfelvétel 
összege fedezte a hiteltörlesztés összegét, valamint a müködés és befektetések pénzeszköz szükségletét.

1998-ban kedvezőtlen változásként értékelhető, hogy a pénzeszközváltozás negatív volt. A vállalkozások a szokásos tevékenység során nem tudták a szükséges pénzmennyiséget előteremteni. A készletek mennyisége növekedett, amihez társult az is, hogy a vevőkkel szembeni követelések (például a fizetési határidők növelése következtében) szintén emelkedtek. Jelentős maradt a beruházás mértéke. A befektetett eszközök beszerzésében a jól müködő vállalkozásoknak megfelelően kis szerep jutott a régebbi eszközök értékesítéséből származó pénzbevételnek. A fejlesztés és a müködés finanszírozása egyaránt hitelekből valósult meg.

1999-ben megmaradt a kedvezőtlen tendencia, az összességében negatív cash flow. Azaz a finanszírozási müveletek pénzbevétele sem tudta fedezni a müködés és a fejlesztés területén kialakult pénzeszköz deficitet. Szembetünő az egyéb rövid lejáratú kötelezettségek csökkenése, a vevők és a készletek növekedése. A befektetések pénzszükségletét kis részben fedezte a befektetett eszközök értékesítése. A felvett hitel nagy része hiteltörlesztésre fordították.

Néhány Szabolcs-Szatmár-Bereg megyei mezőgazdasági vállalkozás 1997-1999 közötti cash flow-kimutatás adatainak átlaga

\begin{tabular}{|c|c|c|c|c|c|c|c|c|c|}
\hline \multirow[b]{2}{*}{ Cash flow-kimutatás(1) } & \multicolumn{3}{|c|}{1997} & \multicolumn{3}{|c|}{1998} & \multicolumn{3}{|c|}{1999} \\
\hline & átlag(2) & \begin{tabular}{|c} 
pénze. \\
változás \\
$\%(3)$
\end{tabular} & $\begin{array}{c}\text { mủk. } \\
\text { cash flow } \\
\%(4)\end{array}$ & átlag(2) & \begin{tabular}{|c|} 
pénze. \\
változás \\
$\%(3)$
\end{tabular} & $\begin{array}{c}\text { mük. } \\
\text { cash flow } \\
\%(4)\end{array}$ & átlag(2) & \begin{tabular}{|c} 
pénze. \\
változás \\
$\%(3)$
\end{tabular} & $\begin{array}{c}\text { mük. } \\
\text { cash flow } \\
\%(4)\end{array}$ \\
\hline Müködési cash flow(4) & -11037 & $-141,5$ & $-100,0$ & -6064 & $-103,0$ & $-100,0$ & -4724 & $-96,1$ & $-100,0$ \\
\hline Adózás előtti eredmény $+/-(5)$ & 14809 & 189,8 & 134,2 & 6878 & 116,9 & 113,4 & 12360 & 251,5 & 261,6 \\
\hline Elszámolt amortizáció +(6) & 8082 & 103,6 & 73,2 & 10560 & 179,4 & 174,1 & 11051 & 224,8 & 233,9 \\
\hline Elszámolt értékvesztés +(7) & 18 & 0,2 & 0,2 & 1507 & 25,6 & 24,8 & 2867 & 58,3 & 60,7 \\
\hline Céltartalék képzés és felhasználás különbözete +/-(8) & -45 & $-0,6$ & $-0,4$ & 344 & 5,8 & 5,7 & 29 & 0,6 & 0,6 \\
\hline Befektetett eszközök értékesítésének eredménye +/-(9) & 541 & 6,9 & 4,9 & -449 & $-7,6$ & $-7,4$ & 363 & 7,4 & 7,7 \\
\hline Szállítói kötelezettségek változása +/-(10) & 3572 & 45,8 & 32,4 & 10791 & 183,3 & 177,9 & -2577 & $-52,4$ & $-54,6$ \\
\hline Egyéb rövid lejáratú kötelezettségek változása +/-(11) & -71652 & $-918,3$ & $-649,2$ & 11888 & 201,9 & 196,0 & -12788 & $-260,2$ & $-270,7$ \\
\hline Passzív időbeli elhatárolások változása +/-(12) & -261 & $-3,3$ & $-2,4$ & 3551 & 60,3 & 58,5 & 1698 & 34,5 & 35,9 \\
\hline Vevőkövetelés változása +/-(13) & 13824 & 177,2 & 125,2 & -20566 & $-349,4$ & $-339,1$ & -4579 & $-93,2$ & $-96,9$ \\
\hline Forgóeszközök változása(14) & 19244 & 246,6 & 174,4 & -28841 & $-490,0$ & $-475,6$ & -9106 & $-185,3$ & $-192,8$ \\
\hline Aktív időbeli elhatárolások változása +/-(15) & 1936 & 24,8 & 17,5 & -701 & $-11,9$ & $-11,6$ & -1694 & $-34,5$ & $-35,8$ \\
\hline Fizetett adó (nyereség után) -(16) & -1104 & $-14,2$ & $-10,0$ & -1123 & $-19,1$ & $-18,5$ & -1770 & $-36,0$ & $-37,5$ \\
\hline Fizetett osztalék, részesedés -(17) & 0 & 0,0 & 0,0 & 0 & 0,0 & 0,0 & -803 & $-16,3$ & $-17,0$ \\
\hline Befektetési cash flow(18) & -25499 & $-326,8$ & $-231,0$ & -67321 & $-1143,7$ & $-1110,1$ & -27458 & $-558,7$ & $-581,3$ \\
\hline Befektetett eszközök beszerzése -(19) & -33463 & $-428,9$ & $-303,2$ & -70468 & $-1197,1$ & $-1162,0$ & -33256 & $-676,6$ & $-704,0$ \\
\hline Befektetett eszközök eladása $+(20)$ & 7953 & 101,9 & 72,1 & 3113 & 52,9 & 51,3 & 5779 & 117,6 & 122,3 \\
\hline Kapott osztalék +(21) & 12 & 0,1 & 0,1 & 34 & 0,6 & 0,6 & 19 & 0,4 & 0,4 \\
\hline Finanszírozási cash flow(22) & 44338 & 568,3 & 401,7 & 67499 & 1146,7 & 1113,0 & 27267 & 554,8 & 577,2 \\
\hline Részvénykibocsátás bevétele (tőkebevonás) +(23) & 37300 & 478,1 & 338,0 & 0 & 0,0 & 0,0 & 0 & 0,0 & 0,0 \\
\hline Kötvénykibocsátás bevétele $+(24)$ & 0 & 0,0 & 0,0 & 0 & 0,0 & 0,0 & 0 & 0,0 & 0,0 \\
\hline Hitelfelvétel $+(25)$ & 40002 & 512,7 & 362,4 & 82158 & 1395,7 & 1354,8 & 57828 & 1176,6 & 1224,1 \\
\hline Véglegesen kapott pénzeszközök +(26) & 2856 & 36,6 & 25,9 & 12810 & 217,6 & 211,2 & 18185 & 370,0 & 385,0 \\
\hline Részvénybevonás (tőkeleszállitás) -(27) & -7172 & $-91,9$ & $-65,0$ & 0 & 0,0 & 0,0 & 0 & 0,0 & 0,0 \\
\hline Kötvényvisszafizetés -(28) & 0 & 0,0 & 0,0 & 0 & 0,0 & 0,0 & 0 & 0,0 & 0,0 \\
\hline Hiteltörlesztés-visszafizetés -(29) & -28576 & $-366,3$ & $-258,9$ & -31091 & $-528,2$ & $-512,7$ & -52153 & $-1061,1$ & $-1104,0$ \\
\hline Véglegesen átadott pénzeszközök -(30) & -72 & $-0,9$ & $-0,7$ & 3622 & 61,5 & 59,7 & 5680 & 115,6 & 120,2 \\
\hline Pénzeszköz változás(3) & 7802 & 100,0 & 70,7 & -5886 & $-100,0$ & $-97,1$ & -4915 & $-100,0$ & $-104,0$ \\
\hline
\end{tabular}

Table 2: Some Szabolcs-Szatmár-Bereg country agricultural companies 1997-1999 average cash flow statment

Cash flow statment(1), Average(2), Cash flow(3), Operative cash flow(4), Pre-tax profit(5), Accounted depreciation(6), Accounted loss in value(7), Provisions change(8), Achievement of invested assets sale(9), Trade creditors change(10), Other short term liabilities change(11), Accrued liabilities change(12), Trade debtors change(13), The change of current assets (without trade debtors and cash)(14), Accruals change(15), Paid tax(16), Paid dividend(17), Investment cash flow(18), Invested assets bay(19), Invested assets sale(20), Received dividend(21), Financial cash flow(22), Share issue capture(23), Flotation capture(24), Credit admission(25), Cash received permanently(26), Withdra wal of stocks(27), Bond refund(28), loan repayments(29), Cash handed over permanently(30) 


\section{KÖVETKEZTETÉSEK}

Ezen értékelés alapján talán a két megye mezőgazdasági vállalkozásai közül a SzabolcsSzatmár-Bereg megyei vállalkozások helyzete kedvezőtlenebb, mivel a pénzeszköz-változásuk átlagosan negatívan alakul. A müködési cash flow nem fedezte a vállalkozás pénzeszközszükségletét. A befektetések pénzszükséglete általában hitelből fedezhetö. A felvett hitelek nagy része, pedig a korábbi hitelek törlesztésére fordítódik.

A Hajdú-Bihar megyei vállalkozások esetében 1999-re kedvezö változások következtek be. A kívánatosnak megfelelően a szokásos tevékenység pénzbevétele pozitívan alakult, ami fedezni tudta a befektetéseket, a hiteltörlesztések nagy részét, amit szükség esetén hitelek felvételével is kiegészítettek.

Összességében két megye mezőgazdasági vállalkozásai közül ezen elemzés alapján nem adható egyértelmü válasz arra vonatkozóan, hogy melyik megye mezőgazdasági vállalkozásai vannak jobb helyzetben, illetve a kialakult eltérések mire vezethetők vissza. A rendelkezésre álló adatok alapján ezen kérdésekre nem lehet egyértelmü választ adni, de a későbbiekben ennek megítélése érdekében további vizsgálatokat és kiegészítő adatgyüjtést fogok végezni.

\section{IRODALOM}

Bíró T.-Pucsek J.-Sztanó I. (1997): A vállalkozások tevékenységének komplex elemzése. Perfekt Pénzügyi Szakoktató és Kiadó Részvénytársaság, Budapest

Collins, J. M. (1998): Cashflow- és likviditásmenedzsment. Ernst and Young

Koblencz J. (1995): Ködoszlatás cash flow ügyben. Számvitel és Könyvvizsgálat, 11-12.
Kozma A. (1999): Vázlatok a számvitel tanulmányozásához. Egyetemi jegyzet, Debrecen

Nagy I. (1997): Cash flow-kimutatás. Auditinfó Kiadó Kft., Budapest

Tóth P. (1993): Számvitel és Pénzgazdálkodás. Mezőgazda Kiadó, Budapest

2000. évi C. törvény a számvitelről 